\title{
Phylogeny and biogeography of the narrowly endemic Doronicum cataractarum (Asteraceae) from the eastern European Alps: Pleistocene origin from Alpine ancestors rather than Tertiary relic with southwest Asian affinity
}

\author{
Stefanie Skof ${ }^{1} \cdot$ Ines Álvarez ${ }^{2} \cdot$ Clemens Pachschwöll $^{1} \cdot$ Gerald M. Schneeweiss ${ }^{1}(\mathbb{D}$
}

Received: 11 May 2018 / Accepted: 17 November 2018 / Published online: 28 November 2018

(c) The Author(s) 2018

\begin{abstract}
Distribution areas of narrowly endemic species in the European Alps often coincide with Pleistocene refugia, suggesting that allopatric divergence due to Pleistocene range shifts might have been instrumental in their origin. Here, we infer the phylogenetic position of the locally endemic Doronicum cataractarum testing previous hypotheses with respect to its biogeographic and temporal origin (Tertiary origin with southwest Asian affinities versus possibly Pleistocene origin in the Alps). To this end, we extended existing genus-wide data sets of nuclear and plastid DNA sequences and obtained sequences from two hitherto not used low copy nuclear markers. These data sets were analyzed, as single markers and jointly in a concatenated matrix, using maximum parsimony and maximum likelihood. Temporal and spatial origins of $D$. cataractarum were inferred using mean path lengths and dispersal-vicariance analysis, respectively. Phylogenetic resolution was limited, but several geographically coherent groups were identified, including the Grandiflora group comprising southern and central European mountain species. Congruently, D. cataractarum was inferred as most closely related to Alpine species from the Grandiflora group (D. clusii, D. stiriacum and D. glaciale), but neither to southwest Asian species nor to European D. austriacum. The origin of $D$. cataractarum was conservatively dated to about 1.9 Mya and inferred to have taken place in the Alps. The striking morphological differences between $D$. cataractarum and the most closely related species likely are the result of adaptation to different habitats or, alternatively, the presence of plesiomorphic traits in D. cataractarum.
\end{abstract}

Keywords Asteraceae $\cdot$ Biogeography $\cdot$ Doronicum cataractarum $\cdot$ Molecular phylogeny $\cdot$ Relic

\section{Introduction}

Pleistocene climate fluctuations had major impacts on plant distribution and evolution. During Pleistocene cold periods, large parts of the Arctic and some southern mountain ranges,

Handling Editor: Andreas Tribsch.

Electronic supplementary material The online version of this article (https://doi.org/10.1007/s00606-018-1558-4) contains supplementary material, which is available to authorized users.

Gerald M. Schneeweiss

gerald.schneeweiss@univie.ac.at

1 Department of Botany and Biodiversity Research, University of Vienna, Rennweg 14, 1030 Vienna, Austria

2 Real Jardin Botánico, CSIC, Plaza de Murillo 2, 28014 Madrid, Spain such as the European Alps (hereinafter simply referred to as Alps), were covered with ice sheets (Ehlers and Gibbard 2004), forcing plants into ice-free refugia that were situated either within the ice sheet (nunataks) or at its periphery (Schönswetter et al. 2005; Schneeweiss and Schönswetter 2011; Westergaard et al. 2011; Escobar García et al. 2016). In the Alps, distribution areas of narrowly endemic species often coincide with such refugia, especially peripheral ones (Tribsch and Schönswetter 2003; Tribsch 2004), suggesting that Pleistocene range shifts might have been instrumental in the origin of at least some of these taxa (Casazza et al. 2016). Testing this hypothesis requires that such taxa are placed within a phylogenetic framework (Conti et al. 1999; Zhang et al. 2004; Fior and Karis 2007).

One of those locally endemic species, whose phylogenetic position and thus biogeographic history have been controversial, is Doronicum cataractarum Widder (Asteraceae). 
This species is restricted to a single mountain in the easternmost Alps, Mount Koralpe (Fig. 1a), which was situated outside the continuous ice sheet and was only locally glaciated (van Husen 1987). Here, the species is found in rocky places or gullies next to watercourses mainly in (montane to) subalpine alder krummholz (Fig. 1b) and subalpine to alpine tall herb communities (Fig. 1c) between 1500 and $1800 \mathrm{~m}$ a. s. 1. (Álvarez Fernández 2003; Essl 2009). Doronicum cataractarum was discovered in 1853 , but initially erroneously considered to belong to $D$. pardalianches $\mathrm{L}$. Only about 70 years later, it was recognized and described as a new species (Widder 1925). For the placement of $D$. cataractarum within the genus, Widder (1925) followed the classification of Doronicum L. by Cavillier (1907, 1911), the then latest monograph of the genus. Cavillier divided Doronicum into three sections, the largest of which, sect. Doronicastrum Cavill., is grouped into seven subsections (Corsica Cavill., Grandiflora Cavill., Austriaca Cavill., Macrophylla Cavill., Plantaginea Cavill., Pardalianchia Cavill. and Cardiophylla Cavill.). Diagnostic characters used by Cavillier included the number of heads, the number of bracts, the size, shape and nervature of the basal leaves and the morphology of achenes (Cavillier 1907, 1911). Based on the tall growth, the multiheaded synflorescences, the relatively long internodes, the high number of basal leaves, the shallowly cordate leaf bases (Fig. 1d) and the lack of a pappus on the ray florets, Widder (1925) assigned D. cataractarum to subsect. Macrophylla, which otherwise includes exclusively southwest Asian species (D. macrophyllum Fisch. s.l., D. dolichotrichum Cavill., D. haussknechtii Cavill., D. maximum Boiss. \& A.Huet, D.

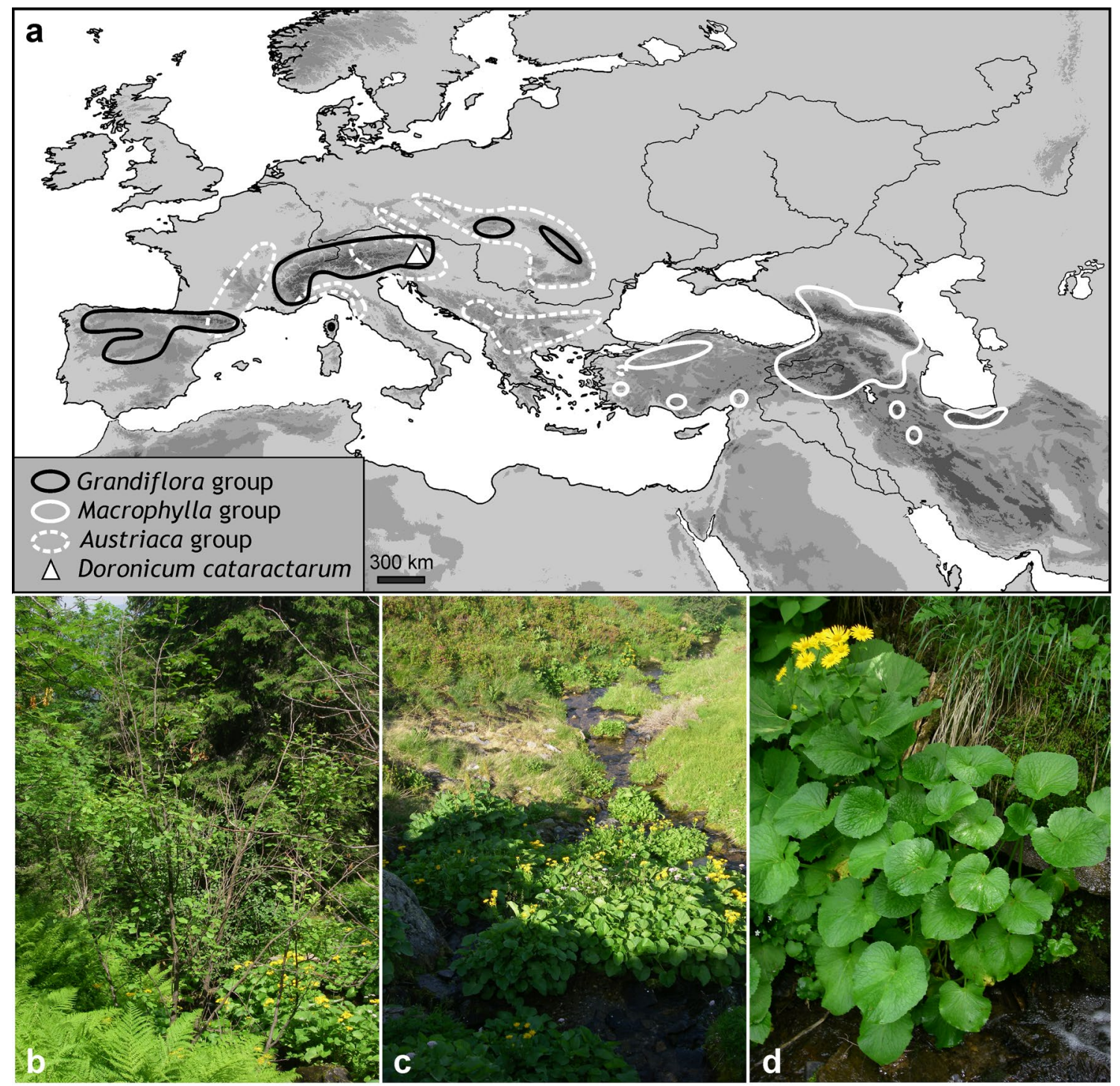

Fig. 1 Distribution (a) of Doronicum cataractarum and informal Doronicum groups that have been suggested to be closely related to it (see text for details) in Europe and southwest Asia as well as habitats $(\mathbf{b}, \mathbf{c})$ and habit $(\mathbf{d})$ of $D$. cataractarum 
cacaliifolium Boiss. \& Heldr. and D. reticulatum Boiss.). Although this placement of $D$. cataractarum was later questioned by Edmondson (1978) based on morphological characters (D. cataractarum has a woolly tuft at the apex of its rhizome absent in members of subsect. Macrophylla), Widder's assignment has been widely followed in the literature (Wagenitz 1987, Meusel and Jäger 1992).

In contrast, in her monograph of Doronicum Álvarez Fernández (2003) suggested that $D$. cataractarum belongs to the (informally named) Austriaca group with, based on morphology, the most closely related species being $D$. austriacum Jacq. Whereas $D$. cataractarum has scarcely pubescent to pubescent rhizomes, a capitulum base that is glabrous or glabrate with short-stalked or subsessile trichomes and an occasionally present pappus on the ray florets, $D$. austriacum possesses glabrous rhizomes, a capitulum base that is glabrate to pubescent with long-stalked trichomes and ray florets that always lack a pappus.

These alternative classifications of D. cataractarum imply two hypotheses concerning the species' origin. According to Widder (1925), D. cataractarum represents the westernmost member of subsect. Macrophylla (hereinafter referred to as Macrophylla group), whose remaining species are found from the Caucasus and the Armenian highland west to Asia Minor (Fig. 1a). Widder (1925) interpreted the highly disjoint distribution of the Macrophylla group as the result of vicariant speciation into higher elevations from a Tertiary ancestor of subtropical woodlands. Based on the perceived systematic isolation within the Macrophylla group, the restriction to very specific habitats, the lack of morphological variation and the highly fragmented occurrence on Mount Koralpe, Widder (1925) argued that D. cataractarum "with certainty is a representative of the Tertiary ancestral flora" (translated from German). In contrast, according to Álvarez Fernández (2003), D. cataractarum is most closely related to $D$. austriacum, whose wide distribution area (ranging from the eastern Pyrenees to the Carpathians, Balkan Peninsula and western Turkey) includes the Alps and Mount Koralpe (Fig. 1a). This presumed close relationship to $D$. austriacum implies an origin of $D$. cataractarum in the Alps that may be younger than envisaged by Widder (1925).

The main objective of this study is to clarify the phylogenetic position of $D$. cataractarum, thus testing previous hypotheses of Widder (1925) and Álvarez Fernández (2003). To this end, we use nuclear (ITS) and plastid DNA sequences (trnL-F) employed previously (Álvarez Fernández et al. 2001) as well as two low copy nuclear genes (A25, A39) that have been successfully used in other Asteraceae (Chapman and Burke 2007). Based on the thus obtained phylogenetic hypothesis, we conduct a coarse molecular dating analysis to test a Tertiary origin of $D$. cataractarum as suggested by Widder (1925) and use biogeographic reconstructions to test hypotheses of a southwest Asian (Widder 1925) versus an Alpine affinity (Álvarez Fernández 2003) of $D$. cataractarum.

\section{Materials and Methods}

\section{Molecular methods}

Total genomic DNA was extracted from 59 specimens from fresh or from herbarium material (Online Resource 1) following the CTAB protocol (Doyle and Doyle 1987) with minor modifications (leaving both the sorbitol washing step and the isopropanol precipitation step overnight) or using extraction kits (peqGOLD Plant DNA mini kit: Peqlab, Darmstadt, Germany; DNeasy Plant mini kit: Qiagen, Vienna, Austria) following the manufacturers' instructions. The sampling includes 27 species of Doronicum (some of those with subspecies) and 4 species of Abrotanella as outgroup (Pelser et al. 2007). Species classification follows Álvarez Fernández et al. (2003) and Pachschwöll et al. (2015).

To allow combination with previously generated data sets of Álvarez Fernández et al. (2001), the plastid trnL-F region (comprising the trnL $\mathrm{L}_{\mathrm{UAA}}$ intron, the second exon of the $\operatorname{trn} \mathrm{L}_{\mathrm{UAA}}$ gene and the $\operatorname{trnL}_{\mathrm{UAA}}-\mathrm{trnF}_{\mathrm{GAA}}$ intergenic spacer) and the nuclear ITS region (comprising internal transcribed spacers 1 and 2 and the intervening 5.8S gene) were amplified. Available data sets of the plastid trnL $\mathrm{L}_{\mathrm{UAA}}$ intron and the two internal transcribed spacers of the nuclear 35S rDNA (Álvarez Fernández et al. 2001) were complemented with those newly obtained sequences. The plastid trnL-F region was amplified using primers $\mathrm{c}$ and $\mathrm{f}$ (Taberlet et al. 1991); in cases where these primers did not amplify (due to insufficient DNA quality), the trnL intron and the trnL-trnF intergenic spacer were amplified separately using primer pair $\mathrm{c}$ and $\mathrm{d}$ and primer pair e and $\mathrm{f}$, respectively (Taberlet et al. 1991). Likewise, whenever possible the two internal transcribed spacers were amplified jointly using primers AB 101 and AB102 (Sun et al. 1994); if these primers failed, ITS 1 and ITS 2 were amplified separately using primer pair ITS2 and ITS5c and primer pair ITS 3 and ITS4, respectively (White et al. 1990). Additionally, several nuclear low copy markers suggested by Chapman et al. (2007) were tested. Of eight regions tested (A19, A25, A28, A39, B07, B12, B27 and C32), A25 and A39 showed consistent amplification and sufficient levels of variation and were, therefore, chosen. PCR for all samples and all of the primers was performed in a total volume of about $16 \mu \mathrm{l}$ containing $7 \mu \mathrm{l}$ water, $7 \mu \mathrm{l}$ Kapa 3G Buffer, $0.7 \mu \mathrm{l}$ of undiluted (for ITS only) or 1:50 diluted DNA extract of unknown concentration, $0.5 \mu \mathrm{l}$ forward primer, $0.5 \mu \mathrm{l}$ reverse primer (from a $10 \mu \mathrm{M}$ stock) and $0.12 \mu \mathrm{l}$ Kapa $3 \mathrm{G}$ polymerase (Kapa Biosystems, London, UK). For ITS amplification, the PCR conditions were: 4 min 
at $94{ }^{\circ} \mathrm{C}$ followed by 35 cycles each of $1 \mathrm{~min}$ at $94{ }^{\circ} \mathrm{C}, 1 \mathrm{~min}$ at $47{ }^{\circ} \mathrm{C}$ and 1 min at $72{ }^{\circ} \mathrm{C}$ followed by a final extension period of $10 \mathrm{~min}$ at $72{ }^{\circ} \mathrm{C}$. For the trnL-F region, the PCR conditions were: $1 \mathrm{~min} 30 \mathrm{~s}$ at $94^{\circ} \mathrm{C}$ followed by 35 cycles each of $15 \mathrm{~s}$ at $94{ }^{\circ} \mathrm{C}, 15 \mathrm{~s}$ at $51{ }^{\circ} \mathrm{C}$ and $1 \mathrm{~min} 30 \mathrm{~s}$ min at $72{ }^{\circ} \mathrm{C}$ followed by a final extension period of $10 \mathrm{~min}$ at $72{ }^{\circ} \mathrm{C}$. PCR conditions for the low copy markers were those used by Chapman et al. (2007). The PCR products were cleaned with a mix containing $1 \mu \mathrm{l}$ FastAP and $0.5 \mu \mathrm{l}$ Exo I following the manufacturer's instructions (Thermo Scientific, Vienna, Austria). Cycle sequencing was performed in $10 \mu \mathrm{l}$ volumes containing either $5 \mu \mathrm{l} \mathrm{PCR}$ product, $2 \mu \mathrm{l}$ trehalose, $1.5 \mu$ l sequencing buffer, $1 \mu$ BigDye and $0.5 \mu \mathrm{l}$ primer or containing 5.3 $\mu \mathrm{l}$ PCR product, $2 \mu \mathrm{l}$ trehalose, $1.6 \mu \mathrm{l}$ sequencing buffer, $0.6 \mu \mathrm{l}$ BigDye and $0.5 \mu \mathrm{l}$ primer. The products were cleaned with Sephadex G-50 Fine (GE Healthcare Bio-Sciences, Uppsala, Sweden) and sequenced on an ABI 3730 DNA Analyzer capillary sequencer (Applied Biosystems, Foster City, USA).

\section{Data analyses}

Sequences were assembled using SeqMan II 5.05 (DNAStar, Madison, WI) and manually edited. Ambiguities (double peaks where the lower peak was at least one third the height of the higher peak) were coded using IUPAC symbols. Sequences were aligned using MAFFT 7.215 (Katoh and Standley 2013) using as option for iterative refinement G-INS-i (recommended for sequences with global homology). Alignments were manually edited with BioEdit 7.2.5 (Hall 1999).

Single marker data sets and a combined data set, including only samples with sequences from at least two markers available (Online Resource 1), were analyzed phylogenetically. Maximum parsimony (MP) analyses were conducted in PAUP* 4b10 (Swofford 2003) employing a heuristic search with 1000 random sequence addition replicates, TBR branch swapping and saving no more than 100 trees per replicate. Clade support was assessed using bootstrapping with 1000 bootstrap replicates employing a heuristic search with 100 random sequence addition replicates, tree bisection and reconnection (TBR) branch swapping and saving no more than 10 trees per replicate. Maximum likelihood (ML) analyses were conducted in RAxML 8.0.17 (Stamatakis 2014) using 1000 bootstrap replicates, obtained by the rapid bootstrap algorithm (Stamatakis et al. 2008), as starting points for the search for the ML tree. Data matrices and phylogenetic trees (strict consensus trees from maximum parsimony analyses, maximum likelihood trees) are available in TreeBase at http://purl.org/phylo/treebase/phylows/ study/TB2:S23249.

An ultrametric tree was obtained from the ML tree of the combined data using PATHd8 (Britton et al. 2007) after pruning the outgroup Abrotanella. We set the crown node age of Doronicum (i.e., the root node of our pruned tree) to 17.1 or $21.9 \mathrm{Ma}$. As these are the confidence interval of the stem node age of Abrotanella (Wagstaff et al. 2006; Torices 2010), i.e., the node pertaining to the common ancestor of Doronicum and Abrotanella, we are conservative with respect to the hypothesis of a Tertiary origin of $D$. cataractarum (Widder 1925).

Biogeographic reconstructions were done using dispersal-vicariance analysis (DIVA; Ronquist 1997) implemented in RASP 3.2 (Yu et al. 2015), setting the number of maximally allowed areas per node to 2 (only three species occur in more than 2 areas), as well as unordered maximum parsimony implemented in Mesquite 3.2 (Maddison and Maddison 2017). Due to the presence of many poorly supported short branches (both at terminals and at the backbone) in the tree and the inclusion of multiple samples per species causing multiplication of a species' distribution area in the geographic data, we refrained from using likelihood-based models of biogeographic inference, such as the dispersal-extinction-cladogenesis (DEC) model (Ree and Smith 2008). Geographic regions were delimited based on biogeographic (presence of endemic Doronicum taxa) and

Table 1 Sequence statistics

\begin{tabular}{|c|c|c|c|c|c|}
\hline & $\operatorname{trnL}-\mathrm{F}$ & ITS & A25 & A39 & Combined data \\
\hline Sequence length raw data & $799-894$ & $661-743$ & $394-425$ & $521-554$ & \\
\hline Alignment length & 894 & 743 & 425 & 554 & 2611 \\
\hline Amount of missing data (\%) & 20.07 & 16.31 & 0.40 & 0.91 & 30.14 \\
\hline Number of variable characters & 58 & 238 & 146 & 132 & 516 \\
\hline Number of parsimony-informative characters & 40 & 179 & 99 & 110 & 406 \\
\hline Number of equally most parsimonious trees & 86,200 & 70,400 & 4 & 1001 & 34,000 \\
\hline Tree length & 61 & 424 & 178 & 161 & 784 \\
\hline Consistency index & 0.951 & 0.665 & 0.921 & 0.925 & 0.751 \\
\hline Retention index & 0.980 & 0.874 & 0.951 & 0.941 & 0.869 \\
\hline Likelihood score & -1612.154 & -3480.893 & -1445.687 & -1612.310 & -8352.867 \\
\hline
\end{tabular}


Fig. 2 Phylogenetic relationships of Doronicum inferred from maximum likelihood analysis of nuclear low copy gene A25. Numbers at nodes are bootstrap support values from maximum likelihood (normal font, only values $\geq 50$ are given) and maximum parsimony (in italics); nodes not present in the strict consensus tree from maximum parsimony are those without any support values given (i.e., nodes that do not have support from the maximum likelihood analysis either) and those indicated by arrowheads (i.e., nodes that have support from the maximum likelihood analysis). Single letter codes before the species name indicate assignment to one of three informal groups of interest: A, Austriaca group; G, Grandiflora group; M, Macrophylla group

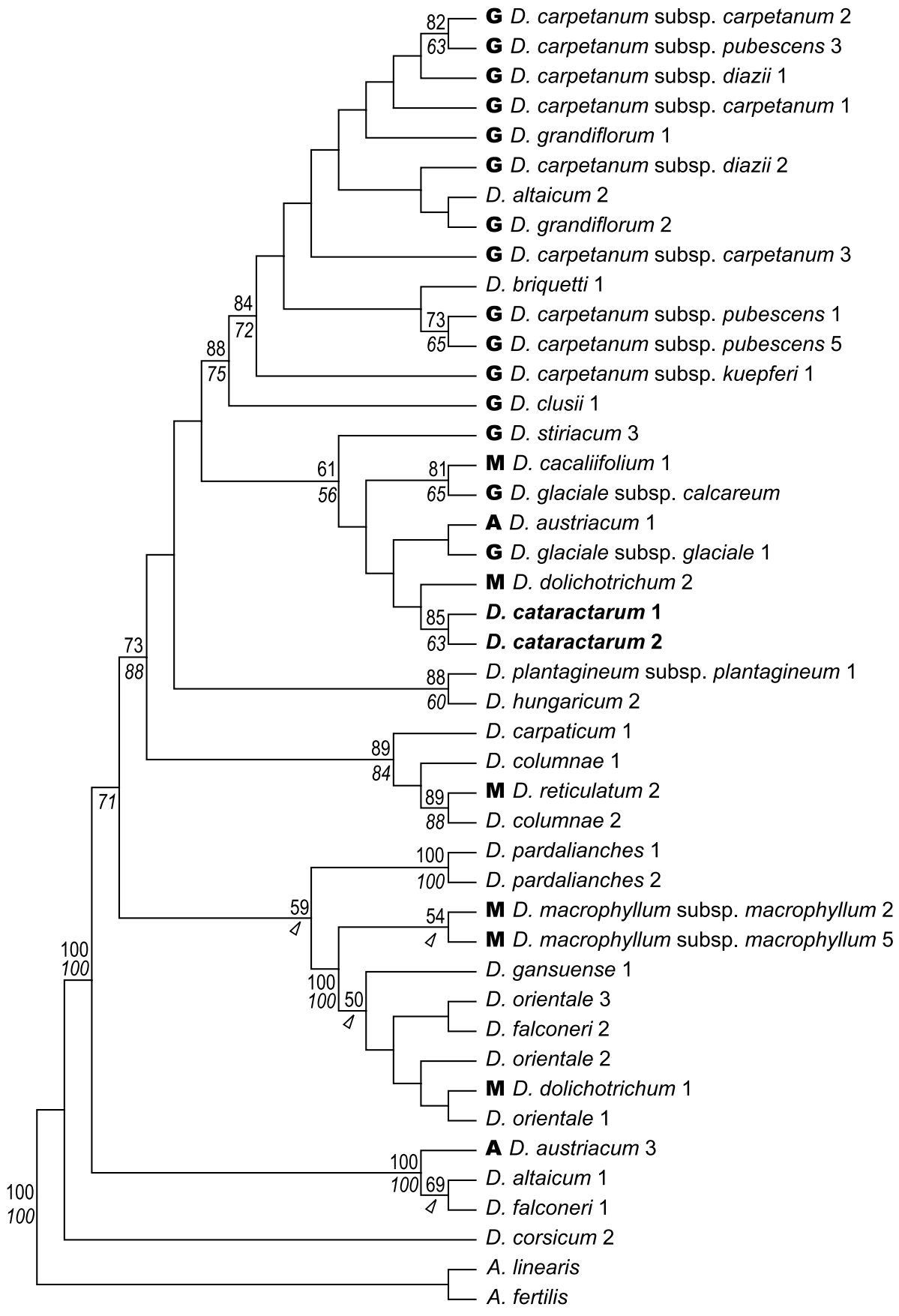

geographic-ecological considerations (mountain ranges vs. lowland regions, Mediterranean vs. temperate zones). Thus, the following eight regions were distinguished: (1) West Mediterranean, (2) East Mediterranean, (3) Pyrenees, Cordillera Cantábrica, Sistema Central and Sistema Iberico, (4) Alps and Apennines, (5) Carpathians and mountain ranges of the Balkan Peninsula, (6) Temperate European Lowland, (7) Southwest Asia and Caucasus, (8) Central and East Asia.

\section{Results}

Single markers differed with respect to the level of resolution and/or support (Figs. 2-3, Online Resources 2-3). These were lowest for the plastid trnL-F data, where the maximum parsimony tree was largely unresolved and most clades inferred by maximum likelihood had bootstrap support values (BS) below 50\% (Online Resource 2). Despite the short lengths of the nuclear low copy markers A25 and A39 (Table 1), phylogenetic analyses resulted in trees 


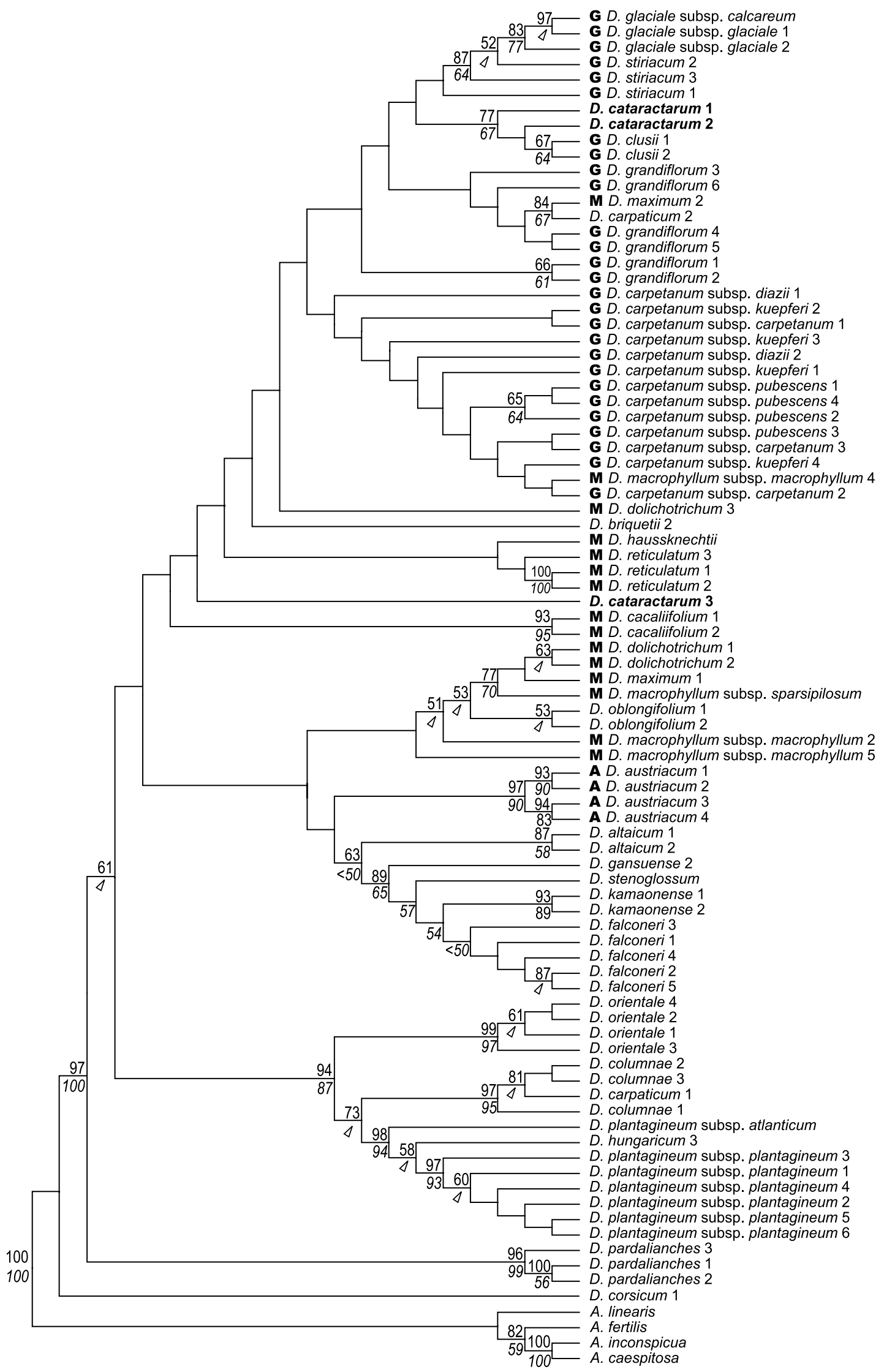


4Fig. 3 Phylogenetic relationships of Doronicum inferred from maximum likelihood analysis of nuclear ITS. Numbers at nodes are bootstrap support values from maximum likelihood (normal font, only values $\geq 50$ are given) and maximum parsimony (in italics); nodes not present in the strict consensus tree from maximum parsimony are those without any support values given (i.e., nodes that do not have support from the maximum likelihood analysis either) and those indicated by arrowheads (i.e., nodes that have support from the maximum likelihood analysis). Single letter codes before the species name indicate assignment to one of three informal groups of interest: A, Austriaca group; G, Grandiflora group; M, Macrophylla group

(Fig. 2, Online Resource 3) with resolution and support comparable to those obtained from nuclear ITS (Fig. 3).

Phylogenetic relationships inferred from single markers were largely congruent among each other, exceptions mainly concerning unresolved and/or poorly supported branches (Figs. 2-3, Online Resources 2-3). A few deviating results were obtained for A25 (Fig. 2). Specifically, a well-supported clade (BS from MP/ML 100/100) containing one accession each of D. austriacum, D. altaicum Pall. and D. falconeri C.B.Clarke ex Hook.f. and another well-supported clade (BS 100/100) including D. orientale Hoffm., D. gansuense Y.L.Chen, D. macrophyllum subsp. macrophyllum (all accessions) and one, but not all, accessions of D. dolichotrichum and D. falconeri (BS 100) plus D. pardalianches (ML only; BS 59) were not recovered by any other marker. The reasons for these discrepancies are unclear (direct sequencing resulted in clear reads, rendering the presence of two or more divergent copies unlikely). As these local discrepancies affected only a single locus, we combined all loci and in the following exclusively focus on the results from the combined analyses (Fig. 4).

Doronicum was clearly separated from the outgroup Abrotanella (BS 100/100). Within Doronicum, D. corsicum (Loisel.) Poir. was inferred as sister to the remainder of the genus (BS 100/100). Doronicum pardalianches (BS 100/100) and D. orientale (BS 98/100) were consecutive sister groups to the remainder of the genus (BS 54/67 and BS $58 / 70$, respectively). Resolution within the clade containing all species except $D$. corsicum, $D$. orientale and $D$. pardalianches was generally low. One well-supported clade (BS 93/95) was congruently identified, comprising two subclades containing D. columnae Ten. and D. carpaticum (Griseb. \& Schenk) Nyman (BS 99/100) and D. hungaricum Rchb.f. and D. plantagineum L. s.l. (BS 83/93), respectively.

Doronicum cataractarum was a member of the Grandiflora group (D. carpetanum Boiss. \& Reut. ex Willk. \& Lange s.1., D. clusii (All.) Tausch, D. glaciale (Wulfen) Nyman s.l., D. grandiflorum Lam. and D. stiriacum (Vill.) Dalla Torre), which formed a congruently inferred, yet not supported clade $(\mathrm{BS}<50 /<50)$. A sample of $D$. dolichotrichum (a species of the Macrophylla group) was placed within the Grandiflora group by ML, while it was inferred as sister to the Grandiflora group by MP, but none of these positions received sufficient bootstrap support. Generally, relationships among members of the Grandiflora group were poorly resolved (Fig. 4), which also affected the position of $D$. cataractarum. Including data of $D$. cataractarum from GenBank (only ITS sequences available and, therefore, not included in the combined data set), D. cataractarum was biphyletic with newly obtained sequences grouping with $D$. clusii s.s. (BS 67/77) and the GenBank sequence occupying an unresolved position outside the Grandiflora group (Fig. 3).

The Macrophylla group (D. cacaliifolium, D. dolichotrichum excluding the sample from GenBank, $D$. haussknechtii, D. macrophyllum s.l., D. maximum and D. reticulatum) did not constitute a clade, but formed a grade toward an unsupported clade of mostly Central and East Asian species (D. altaicum, all but one accession from $D$. falconeri, D. gansuense, D. kamaonense (DC.) Alv.Fern., D. stenoglossum Maxim.). Inferred relationships among and within species did not receive any notable bootstrap support, which was also true for the position of accessions from Central Asian taxa (D. briquetii Cavill. and accession 2 of D. falconeri) outside the Central to East Asian clade. The Austriaca group, including only D. austriacum, did not form a clade, but was biphyletic. Whereas samples from southeastern Europe (Greece, Macedonia) constituted a distinct lineage (BS 89/96) as sister to the Grandiflora group (ML: without support) or at an unresolved position (MP), the sample of $D$. austriacum from the Alps was congruently placed within the Central to East Asian clade (BS 52/56).

The age of the most recent common ancestor of $D$. cataractarum and its sister lineage was estimated to be about 1.7-2.2 Ma. Biogeographic reconstruction inferred an origin of D. cataractarum in the Alps without any southwest Asian affinity. The ancestral area at the root of Doronicum was reconstructed as West Mediterranean plus Temperate European Lowland. Ancestral areas at subsequent nodes (pertaining to the clade including all Doronicum species except $D$. corsicum and to the clade additionally excluding $D$. orientale and D. pardalianches) included the Temperate European Lowland, either alone or jointly with other areas (Fig. 4).

\section{Discussion}

Increasing the amount of sequence data in terms of both the number of species (D. cataractarum and D. carpaticum have been included for the first time) and the number of loci (by including two low copy gene markers) results in better-resolved trees compared to those obtained by Álvarez Fernández et al. (2001). Inferences based on the two low 


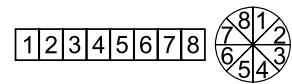

1 West Mediterranean

2 East Mediterranean

3 Pyrenees, Iberian mountain ranges

4 Alps, Apennines

5 Carpathians, mountain ranges

of Balkan Peninsula

6 temperate European lowland

7 Southwest Asia, Caucasus

8 Central and East Asia

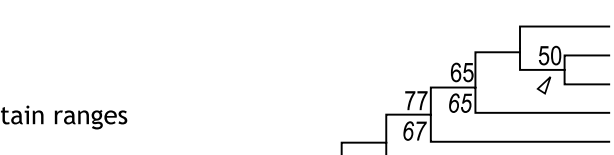

G D. carpetanum subsp. carpetanum 3

G D. carpetanum subsp. pubescens 5

67

G D. carpetanum subsp. pubescens 1

G D. carpetanum subsp. carpetanum 2

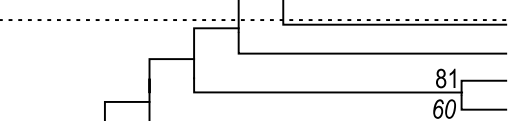

G D. carpetanum subsp. pubescens 3

M D. dolichotrichum 3

G D. carpetanum subsp. carpetanum 1

G D. carpetanum subsp. pubescens 4

G D. carpetanum subsp. diazii 2
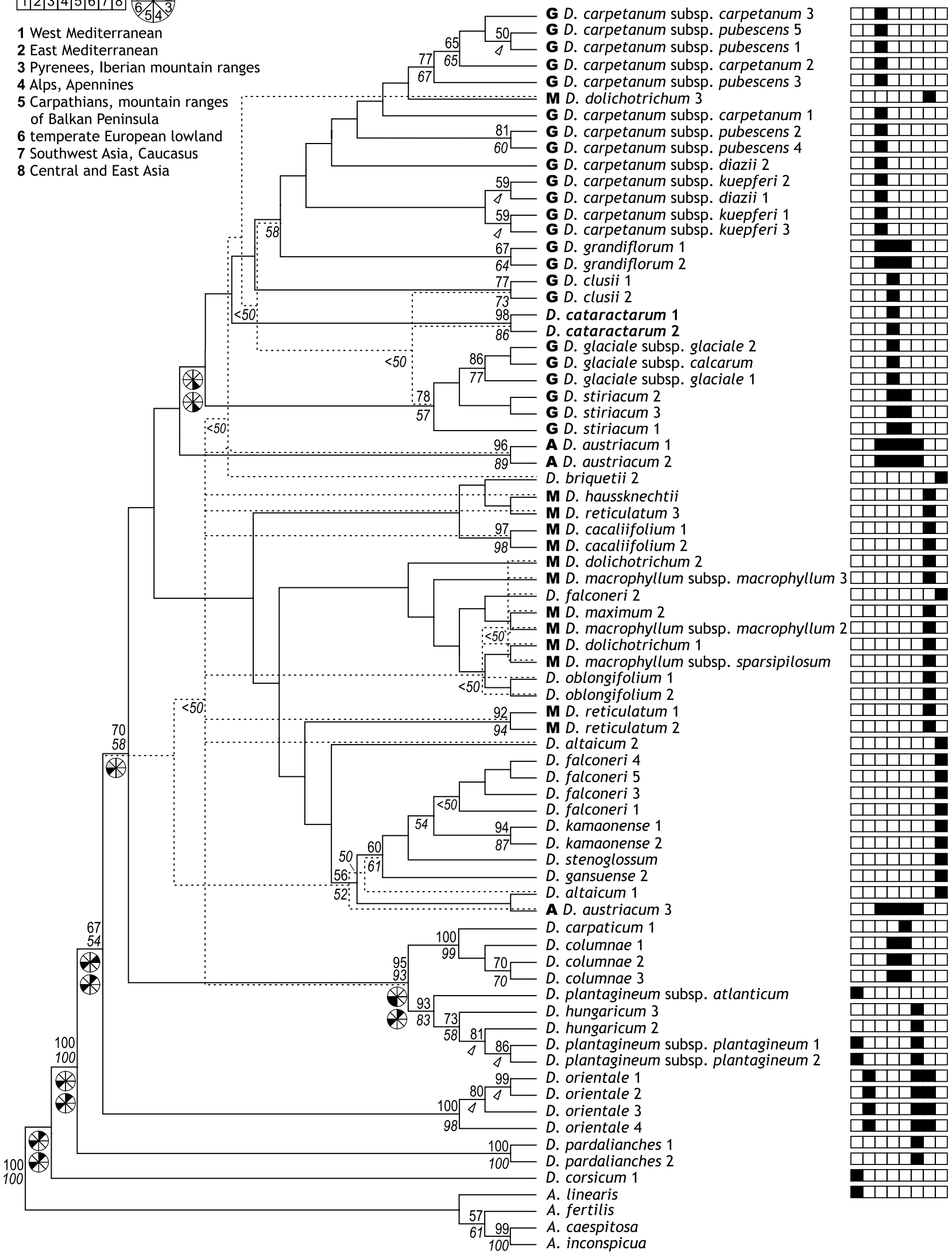
४Fig. 4 Phylogenetic relationships of Doronicum inferred from maximum likelihood analysis of combined data. Alternative relationships inferred by maximum parsimony indicated by dashed lines. Numbers at nodes are bootstrap support values from maximum likelihood (normal font, only values $\geq 50$ are given) and maximum parsimony (in italics); nodes not present in the strict consensus tree from maximum parsimony are those without any support values given (i.e., nodes that do not have support from the maximum likelihood analysis either) and those indicated by arrowheads (i.e., nodes that have support from the maximum likelihood analysis). Geographic distribution of species is shown to the right of each accession name, ancestral areas reconstructed via dispersal-vicariance analysis (upper chart) and maximum parsimony (lower chart) are shown at selected nodes (in case of reconstruction uncertainty, not congruently inferred areas are indicated in gray). Single letter codes before the species name indicate assignment to one of three informal groups of interest: A, Austriaca group; G, Grandiflora group; M, Macrophylla group

copy gene markers used here mostly corroborate relationships inferred from other markers, including the position of this study's focal species $D$. cataractarum. Of the regions used, plastid trnL-F provides insufficient phylogenetic signal in Doronicum, and likely other markers from the plastid genome (Pachschwöll et al. 2015) are more suitable. However, as plastid genealogies may deviate from species phylogenies (due to, for instance, hybridization and chloroplast capture: Rieseberg and Soltis 1991), using additional low copy markers (only a small subset of those tested by Chapman et al. 2007, has been included here) in combination with the application of NGS-based techniques (McKain et al. 2018) will be needed to achieve higher phylogenetic resolution within Doronicum.

Phylogenetic analyses congruently, albeit not necessarily well supported, suggest that $D$. cataractarum belongs to the Grandiflora group, where it may be most closely related to the mainly Alpine D. clusii agg. (D. clusii s.s., D. glaciale s.l. and D. stiriacum: Pachschwöll et al. 2015), instead of to the Macrophylla group (Widder 1925) or the Austriaca group (Álvarez Fernández 2003). This is unexpected given the morphology of D. cataractarum. As emphasized by Widder (1925), D. cataractarum shares with species of the Macrophylla group the tall growth, the multi-headed synflorescences, the high number of basal leaves, the shallowly cordate leaf bases and the lack of a pappus. Similarly, Álvarez Fernández (2003) has noticed that differences between $D$. cataractarum and D. austriacum are only small (rhizomes pubescent to scarcely pubescent in $D$. cataractarum versus glabrous in D. austriacum; base of the capitula glabrous to glabrate with short-stalked or subsessile glandular trichomes in $D$. cataractarum versus glabrate to pubescent or with long-stalked glandular trichomes in D. austriacum). In contrast, species of the Grandiflora group are usually smaller (usually less than $1 \mathrm{~m}$ tall vs. D. cataractarum at least $1 \mathrm{~m}$ ), have fleshy to woody rhizomes with whitetinted short trichomes at the nodes (vs. at least somewhat woody rhizomes that are at least scarcely pubescent in $D$. cataractarum), ovate-elliptic to narrowly elliptic or slightly fiddle-shaped lower and middle cauline leaves that are maximally $10-\mathrm{cm}$-long and maximally 6 -cm-wide (vs. bigger (7-19×6-15 cm) fiddle-shaped leaves in D. cataractarum) and one-, rarely few-headed (up to 6) synflorescences (vs. 2-14-headed synflorescences in D. cataractarum). There are two possible explanations for the striking morphological differences between $D$. cataractarum and its closest relatives of the Grandiflora group. (1) The overall habit of D. cataractarum reflects the primary condition in Doronicum (seen, for instance, also in D. corsicum), and the reduced habit of the species of the Grandiflora group is the result of adaptation into alpine habitats (Álvarez Fernández 2003). (2) Alternatively, the overall habit of $D$. cataractarum may be the result of adaptation to more benign conditions (growing at lower altitudes in places with rich water and nutrient supply) from a $D$. clusii-like ancestor, implying that the morphological resemblance to species like D. macrophyllum or D. austriacum is due to homoplasy. Testing these hypotheses will, however, require ancestral character state reconstruction on a more robust and better-resolved phylogeny. As expected from the close relationship to the D. clusii aggregate of the Grandiflora group, an Alpine origin of D. cataractarum is inferred without any inferred link to southwest Asia as has been suggested by Widder (1925). Likely, D. cataractarum is no Tertiary relic, as suggested by Widder (1925), but rather of Pleistocene origin (the used age calibrations are expected to bias against young ages), although our molecular dating results need to be interpreted with appropriate caution. Evidently, using molecular phylogenetic approaches is crucial in placing endemic species and thus informing about their evolutionary history, as has been done for the enigmatic southwestern Alpine endemics Saxifraga florulenta (Saxifragaceae: Conti et al. 1999; Guerrina et al. 2013) and Berardia subacaulis (Asteraceae: Garcia-Jacas et al. 2002; Fu et al. 2016) or here for D. cataractarum.

Interpretation of phylogenetic relationships in Doronicum is hampered by a poorly resolved backbone and the position of single samples of some species displaced from the remaining samples of the respective species. Examples include $D$. falconeri, $D$. dolichotrichum, or D. cataractarum. The reasons for these discrepancies are unclear, but may be connected to sequence quality (i.e., short sequences from GenBank: D. dolichotrichum and D. cataractarum) or the presence of (unrecognized) paralogues.

Despite these drawbacks several lineages have been congruently identified and often share similar geography (Fig. 4). Some of these lineages comprise single species (D. corsicum, which is sister to all other Doronicum species; D. orientale; $D$. pardalianches), but others are more species-rich, including the Grandiflora group discussed previously and the Plantaginea group. The Plantaginea group of Álvarez Fernández et al. (2001), containing D. columnae, 
D. hungaricum, D. orientale and D. plantagineum s.1., is confirmed after the modification of excluding $D$. orientale and including $D$. carpaticum (Fig. 4). The inclusion of $D$. carpaticum, not studied by Álvarez Fernández et al. (2001), in the Plantaginea group is in line with its close relationship to D. columnae (Pachschwöll 2013). Other groups are mainly defined by geography, including a group of Central and Eastern Asian species (Fig. 4), but these are not statistically significantly supported and morphological synapomorphies have still to be identified.

While phylogenetic resolution usually is too low to permit statements on intraspecific diversification, there is some evidence that $D$. austriacum contains two lineages that may not be each other's closest relatives (Fig. 4; Álvarez et al. 2001). These two lineages correspond to D. austriacum s.s. and the southeastern European D. orphanidis Boiss. (D. austriacum Jacq. subsp. giganteum (Griseb.) Stoj. \& Stef.). Further studies using a broader sampling and a thorough re-evaluation of morphological characters will be necessary to test whether southeastern European populations of D. austriacum constitute a distinct taxon.

Based on the distribution of the early branching lineages of Doronicum in the western Mediterranean region, Álvarez Fernández et al. (2001) and Álvarez Fernández (2003) suggest an origin of the whole genus in the Mediterranean Basin. This is supported by our results from ancestral area reconstructions, where the West Mediterranean is consistently shown to have at least been part of the ancestral area of the entire genus. The ancestral areas inferred at the basal nodes are consistent with the hypothesis that the ancestral Doronicum species was distributed in humid-mild temperate habitats in Europe, from where it reached Middle and East Asia colonizing mountain habitats. European high mountain ranges have been colonized at least twice, once from the European lowlands into the mountain ranges of the Balkan Peninsula and the Carpathians to the Alps and Apennines (D. columnae) and once, possibly from Southwest Asia, into the European high mountain ranges from the Iberian to the Balkan peninsula (Grandiflora group).

Acknowledgements Open access funding provided by University of Vienna. We are grateful to A. Hilpold and P. Schönswetter for collecting plant material, to U. Swenson for providing DNA extracts of some Abrotanella species and to the curators of the herbaria W, WU and LI for permissions to take samples from their herbarium specimens. We thank X. Li, M. Barfuss and E. Grasserbauer for their help in the laboratory. We thank two anonymous reviewers for their comments that significantly improved the manuscript.

\section{Compliance with ethical standards}

Conflict of interest The authors declare that they have no conflict of interest.
Ethical statement The authors comply will all rules of the journal following the COPE guidelines; all authors have contributed and approved the final manuscript.

Open Access This article is distributed under the terms of the Creative Commons Attribution 4.0 International License (http://creativeco mmons.org/licenses/by/4.0/), which permits unrestricted use, distribution, and reproduction in any medium, provided you give appropriate credit to the original author(s) and the source, provide a link to the Creative Commons license, and indicate if changes were made.

\section{Information on Electronic supplementary material}

Online Resource 1. Sampled taxa, localities and voucher information, and GenBank accession numbers.

Online Resource 2. Phylogenetic relationship of Doronicum inferred from maximum likelihood analysis of the plastid trnL-F region.

Online Resource 3. Phylogenetic relationship of Doronicum inferred from maximum likelihood analysis of low copy gene A39.

\section{References}

Álvarez Fernández I (2003) Systematics of Eurasian and North African Doronicum (Asteraceae: Senecioneae). Ann Missouri Bot Gard 90:319-389. https://doi.org/10.2307/3298534

Álvarez Fernández I, Fuertes Aguilar J, Panero JL, Nieto Feliner G (2001) A phylogenetic analysis of Doronicum (Asteraceae, Senecionae) based on morphological, nuclear ribosomal (ITS) and chloroplast (trnL-F) evidence. Molec Phylogen Evol 20:41-64. https://doi.org/10.1006/mpev.2001.0954

Britton T, Anderson CL, Jaquet D, Lundquist S, Bremer K, Anderson $\mathrm{F}$ (2007) Estimating divergence times in large phylogenetic trees. Syst Biol 56:741-752. https://doi.org/10.1080/106351507016137 83

Casazza G, Barberis G, Guerrina M, Zappa E, Mariotti M, Minuto L (2016) The plant endemism in the Maritime and Ligurian Alps. Biogeographia 31:73-88. https://doi.org/10.21426/B631132738

Cavillier F (1907) Étude sur les Doronicum à fruits homomorphes. Annuaire Conserv Jard Bot Genève 10:177-251

Cavillier F (1911) Nouvelles études sur le genre Doronicum. Annuaire Conserv Jard Bot Genève 13-14:195-368

Chapman MA, Burke JM (2007) DNA sequence diversity and the origin of cultivated safflower (Carthamus tinctorius L.; Asteraceae). BMC Pl Biol 7:60. https://doi.org/10.1186/1471-2229-7-60

Chapman MA, Chang JC, Weisman D, Kesseli RV, Burke JM (2007) Universal markers for comparative mapping and phylogenetic analysis in the Asteraceae (Compositae). Theor Appl Genet 115:747-755. https://doi.org/10.1007/s00122-007-0605-2

Conti E, Soltis DE, Hardig TM, Schneider J (1999) Phylogenetic relationships of the silver saxifrages (Saxifraga, sect. Ligulatae Haworth): implications for the evolution of substrate specificity, life histories, and biogeography. Molec Phylogen Evol 13:536555. https://doi.org/10.1006/mpev.1999.0673

Doyle JJ, Doyle JL (1987) A rapid DNA isolation procedure for small amounts of fresh leaf tissue. Phytochem Bull 19:11-15

Edmondson JR (1978) The genus Doronicum L. in Iran. Notes Roy Bot Gard Edinburgh 37:67-73

Ehlers J, Gibbard PL (eds) (2004) Quaternary glaciations-extent and chronology part I: Europe. Elsevier, Amsterdam 
Escobar García P, Winkler M, Flatscher R, Sonnleitner M, Krejčíková J, Suda J, Hülber K, Schneeweiss GM, Schönswetter P (2016) Extensive range persistence in peripheral and interior refugia characterizes Pleistocene range dynamics in a widespread Alpine plant species (Senecio carniolicus, Asteraceae). Molec Ecol 21:1255-1270. https://doi.org/10.1111/j.1365-294X.2012.05456 . $\mathrm{X}$

Essl F (2009) Doronicum cataractarum. In: Essl F, Rabitsch W (eds) Endemiten-Kostbarkeiten in Österreichs Pflanzen- und Tierwelt. Naturwissenschaftlicher Verein für Kärnten, Klagenfurt, \& Umweltbundesamt, Wien, pp 123-124

Fior S, Karis PO (2007) Phylogeny, evolution and systematics of Moehringia (Caryophyllaceae) as inferred from molecular and morphological data: a case of homology reassessment. Cladistics 23:362-372. https://doi.org/10.1111/j.1096-0031.2007.00150.x

Fu ZX, Jiao BH, Nie B, Zhang GJ, Gao TG, China Phylogeny Consortium (2016) A comprehensive generic-level phylogeny of the sunflower family: Implications for the systematics of Chinese Asteraceae. J Syst Evol 54:416-437. https://doi.org/10.1111/jse.12216

Garcia-Jacas N, Garnatje T, Susanna A, Vilatersana R (2002) Tribal and subtribal delimitation and phylogeny of the Cardueae (Asteraceae): a combined nuclear and chloroplast DNA analysis. Molec Phylogen Evol 22:51-64. https://doi.org/10.1006/mpev.2001.1038

Guerrina M, Conti E, Fantini P, Mariotti MG, Marsili S, Minuto L, Roccotiello E, Selvaggi A, Casazza G (2013) Saxifraga florulenta Moretti. In: Rossi G, Foggi B, Gennai M, Gargano D, Montagnani C, Orsenigo S, Pedrini S (eds) Schede per una Lista Rossa Flora vascolare e crittogamica Italiana. Inform Bot Ital 45:178-180

Hall TA (1999) BioEdit: a user-friendly biological sequence alignment editor and analysis program for Windows 95/98/NT. Nucl Acids Symp Ser 41:95-98

Katoh K, Standley DM (2013) MAFFT multiple sequence alignment software version 7: improvements in performance and usability. Molec Biol Evol 30:772-780. https://doi.org/10.1093/molbev/ mst010

Maddison WP, Maddison DR (2017) Mesquite: a modular system for evolutionary analysis. Version 3.2. Available at: http://www. mesquiteproject.org. Accessed 15 Mar 2017

McKain MR, Johnson MG, Uribe-Convers S, Eaton D, Yang Y (2018) Practical considerations for plant phylogenomics. Appl Pl Sci 6:e1038. https://doi.org/10.1002/aps3.1038

Meusel H, Jäger EJ (eds) (1992) Vergleichende Chorologie der zentraleuropäischen Flora 3. Fischer, Jena

Pachschwöll C (2013) Lectotypification of Doronicum carpaticum (Griseb. \& Schenk) Nyman (Asteraceae), with some remarks on its distribution and taxonomy. Contr Bot 48:7-14

Pachschwöll C, Escobar García P, Winkler M, Schneeweiss GM, Schönswetter P (2015) Polyploidisation and geographic differentiation drive diversification in a European high mountain plant group (Doronicum clusii aggregate, Asteraceae). PLoS ONE 10:e0118197. https://doi.org/10.1371/journal.pone.0118197

Pelser PB, Nordenstam B, Kadereit JW, Watson LE (2007) An ITS phylogeny of tribe Senecioneae (Asteraceae) and a new delimitation of Senecio L. Taxon 56:1077-1104. https://doi.org/10.2307/25065 905

Ree RH, Smith SA (2008) Maximum likelihood inference of geographic range evolution by dispersal, local extinction, and cladogenesis. Syst Biol 57:4-14. https://doi.org/10.1080/1063515070 1883881

Rieseberg LH, Soltis DE (1991) Phylogenetic consequences of cytoplasmic gene flow in plants. Evol Trends Pl 5:65-84

Ronquist F (1997) Dispersal-vicariance analysis: a new approach to the quantification of historical biogeography. Syst Biol 46:195-203. https://doi.org/10.1093/sysbio/46.1.195
Schneeweiss GM, Schönswetter P (2011) A re-appraisal of nunatak survival in arctic-alpine phylogeography. Molec Ecol 20:190-192. https://doi.org/10.1111/j.1365-294X.2010.04927.x

Schönswetter P, Stehlik I, Holderegger R, Tribsch A (2005) Molecular evidence for glacial refugia of mountain plants in the European Alps. Molec Ecol 14:3547-3555. https://doi.org/10.1111/j.1365294X.2005.02683.x

Stamatakis A (2014) RAxML version 8: a tool for phylogenetic analysis and post-analysis of large phylogenies. Bioinformatics 30:1312-1313. https://doi.org/10.1093/bioinformatics/btu033

Stamatakis A, Hoover P, Rougemont J (2008) A rapid bootstrap algorithm for the RAxML web servers. Syst Biol 57:758-771. https:// doi.org/10.1080/10635150802429642

Sun Y, Skinner DZ, Liang GH, Hulbert SH (1994) Phylogenetic analysis of Sorghum and related taxa using internal transcribed spacers of nuclear ribosomal DNA. Theor Appl Genet 89:26-32. https:// doi.org/10.1007/BF00226978

Swofford DL (2003) PAUP*: phylogenetic analysis using parsimony $4.0 \mathrm{~b} 10$. Sinauer, Sunderland

Taberlet P, Gielly L, Pautou G, Bouvet J (1991) Universal primers for amplification of three non-coding regions of chloroplast DNA. Pl Molec Biol 17:1105-1109. https://doi.org/10.1007/BF00037152

Torices R (2010) Adding time-calibrated branch lengths to the Asteraceae supertree. J Syst Evol 48:271-278. https://doi.org/10.111 1/j.1759-6831.2010.00088.x

Tribsch A (2004) Areas of endemism of vascular plants in the Eastern Alps in relation to Pleistocene glaciation. J Biogeogr 31:747-760. https://doi.org/10.1111/j.1365-2699.2004.01065.x

Tribsch A, Schönswetter P (2003) Patterns of endemism and comparative phylogeography confirm palaeoenvironmental evidence for Pleistocene refugia in the eastern Alps. Taxon 52:477-497. https ://doi.org/10.2307/3647447

van Husen D (1987) Die Ostalpen in den Eiszeiten. Geologische Bundesanstalt, Wien

Wagenitz G (ed) (1987) Illustrierte Flora von Mitteleuropa VI (4), 2nd edn. Parey, Berlin

Wagstaff SJ, Breitwieser I, Swenson U (2006) Origin and relationships of the austral genus Abrotanella (Asteraceae) inferred from DNA sequences. Taxon 55:95-106. https://doi.org/10.2307/25065531

Westergaard KB, Alsos I, Popp M, Engelskjøn T, Flatberg KI, Brochmann C (2011) Glacial survival may matter after all: nunatak signatures in the rare European populations of two west-arctic species. Molec Ecol 20:376-393. https://doi.org/10.1111/j.1365294X.2010.04928.X

White TJ, Bruns T, Lee S, Taylor JW (1990) Amplification and direct sequencing of fungal ribosomal RNA genes for phylogenetics. In: Innis MA, Gelfand DH, Sninsky JJ, White TJ (eds) PCR protocols: a guide to methods and applications. Academic Press, New York, pp 315-322

Widder FJ (1925) Eine neue Pflanze der Ostalpen-Doronicum (Subsectio Macrophylla) cataractarum und ihre Verwandten. Feddes Repert 22:113-184

Yu Y, Harris AJ, Blair C, He X (2015) RASP (Reconstruct Ancestral State in Phylogenies): a tool for historical biogeography. Molec Phylogen Evol 87:46-49. https://doi.org/10.1016/j.ympev .2015.03.008

Zhang L-B, Comes H-P, Kadereit JW (2004) The temporal course of Quaternary diversification in the European high mountain endemic Primula sect. Auricula (Primulaceae). Int J Pl Sci 165:191-207. https://doi.org/10.1086/380747 